\title{
PEMBINAAN KESADARAN BERAGAMA SEBAGAI UPAYA PENINGKATAN PEMAHAMAN AGAMA ISLAM DI LAPAS KELAS IIB ANAK WANITA TANGERANG
}

\author{
Totong Heri \\ Program Studi Pendidikan Agama Islam, Universitas Muhammadiyah Prof. Dr. \\ HAMKA Jakarta \\ Email: totong_heri@Uhamka.ac.id HP ; 081310433663
}

\begin{abstract}
Correctional institutions are a place of guidance for people who are ensnared by the law. In connection with this coaching, this study tries to describe the activities of Islamic Religious Education held in the Class IIB Lapas for Tangerang female children in an effort to improve religious understanding with the direct observation method. The results of the study that Islamic religious education activities in Lapas class IIB Tangerang female children run well and positively. It was concluded that efforts to increase understanding of Islam were carried out using several methods that were no different from the method of guidance in general. Among them such as the lecture method, the method of learning the Koran, as well as the muhasabah and dhikr methods. The obstacles that occur in Islamic religious education activities are the lack of awareness of prisoners in carrying out the process of religious activities and the lack of attention from the Government in the provision of teaching staff and infrastructure in the implementation of religious activities.
\end{abstract}

Keywords: Understanding, Religious education, Lapas

\begin{abstract}
Abstrak
Lembaga pemasyarakatan merupakan salah satu tempat pembinaan bagi masyarakat yang terjerat hukum. Terkait dengan pembinaan tersebut penelitian ini mencoba mendeskripsikan kegiatan Pendidikan Agama Islam yang diadakan di Lapas Kelas IIB anak Wanita Tangerang dalam upaya meningkatkan pemahaman keagamaan dengan metode observasi langsung. Hasil penelitian bahwa kegiatan pendidikan agama Islam di Lapas klas IIB anak wanita Tangerang berjalan dengan baik dan postif. Disimpulkan bahwa upaya peningkatan pemahaman agama Islam dilakukan dengan menggunakan beberapa metode yang tidak berbeda dari metode bimbingan pada umumnya. Diantaranya seperti metode ceramah, metode pembelajaran al-quran, serta metode muhasabah dan dzikir. Hambatan yang terjadi dalam kegiatan pendidikan agam Islam ini yakni kurangnya kesadaran dari narapidana dalam melaksanakan proses kegiatan keagamaan dan kurangnya perhatian dari Pemerintah dalam pengadaan tenaga pendidik dan sarana prasana dalam pelaksanaan kegiatan keagamaan.
\end{abstract}




\section{Kata Kunci: Pemahaman, Pendidikan Agama, Lapas.}

\section{PENDAHULUAN}

Indonesia sebagai sebuah negara hukum telah mengatur segala aspek kehidupan, mulai dari sosial, politik, ekonomi, pendidikan, dan lain-lain. Akan tetapi tidak dapat dipungkiri bahwa tindak kriminal semakin merajalela. Aparat keamanan semakin gencar menangkap para pelaku kejahatan demi menjaga keamanan masyarakat. Untuk menampung para pelaku kriminalitas tersebut, pemerintah mendirikan Lembaga Pemasyarakatan/Rumah Tahanan Negara. Dengan adanya lembaga pemasyarakatan diharapkan para pelaku kejatan dapat sadar dan bertaubat agar tidak mengulangi kesalahan yang sama.

Para penghuni lembaga pemasyarakatan bukan hanya dari kalangan dewasa, adapula diantaranya yang tergolong usia anak-anak. Anak adalah amanah Allah SWT yang harus dijaga dengan cara diberi pendidikan agar anak tersebut dapat menjalani kehidupan di dunia ini dengan baik. Peralihan anak menuju dewasa dilalui dengan beragam masalah dan tantangan sehingga memunculkan kenakalan pada anak. Istilah anak yang berada dalam lembaga permasyarakatan bukan sebagai "Narapidana Anak" tetapi sebagai “Anak didik permasyarakatan".

Agama merupakan suatu bentuk regulasi Tuhan yang diperuntukkan manusia sebagai pegangan dalam menjalani kehidupan di dunia maupun akherat. Sedangkan agama Islam mengajarkan bagaimana manusia harus bersikap dan bertingkah laku, yaitu selalu berada dalam koridor norma-norma agama untuk menggapai ridho Allah SWT.

Pendidikan agama Islam adalah salah satu cara untuk menyadarkan, membina dan mendidik tahanan di Lapas, sehingga menimbulkan kesadaran dalam diri tahanan bahwa apa yang dikerjakan telah melanggar norma dan etika serta menimbulkan rasa tidak aman dan kerugian baik rugi dari segi finansial maupun psikis korban Hal ini dapat dilihat pada Lembaga Pemasyarakatan Klas II B Anak Wanita Tangerang.

Dengan adanya pembinaan pendidikan Islam bagi para warga binaan lapas bisa memiliki pengetahuan agama yang lebih baik, menumbuhkan dan mengembangkan kesadaran untuk melasanakan ajaran-ajaran agama dalm kehidupan sehari-hari, terutama yang berhubungan dengan ibadah dan akhlaq, serta menimbulkan sikap dan 
suasana kejiwaan yang diliputi oleh nilai-nilai agama seperti: sabar, tawakkal, mutma 'innah, pasrah dan tidak putus asa (Kusnawan, 2011).

Pendidikan agama Islam biasanya dinikmati ditiap jenjang pendidikan seperti SD, SMP, SMA, serta Perguruan Tinggi serta pendidikan luar sekolah seperti majelis ta'lim dan lapas. Mengingat pada umumnya warga binaan kurang memiliki latar belakang pendidikan agama yang memadai baik pendidikan formal maupun pendidikan yang ditanamkan di lingkungan keluarga, hal ini menjadi salah satu faktor yang menarik untuk kami teliti.

Faktor lain yang mempengaruhi pembinaan adalah penyuluh agama yang merupakan ujung tombak Departemen Agama dalam meningkatkan pemahaman dan pengamalan agama yang selanjutnya dapat berpartisipasi aktif dalam pembangunan nasional dengan berhadapan dan langsung berkecimpung di tengah masyarakat (Kusniawan, 2011).

Di Lembaga Permasyarakatan Tangerang pelaksanaaan kegiatan keagamaan dikordinasi melalui seksi bimbingan permasyarakatan, kemudian secara teknis pelaksanaannya diurus oleh bimbingan rohani Islam dan bekerja sama dengan berbagai pihak yang berada diluar lembaga. Berkaitan dengan hal tersebut penulis tertarik untuk melakukan penelitian mengenai upaya peningkatan pemahanan agama Islam yang diterapkan di Lapas tersebut.

\section{Pemahaman}

Asal kata pemahaman yaitu paham yang artinya mengerti benar dalam suatu hal. Sedangkan menurut Anas Sudjiono pemahaman adalah kemampuan seseorang untuk mengerti sesuatu setelah sesuatu itu diketahui dan diingat. Dengan kata lain, memahami adalah mengetahui tentang sesuatu dan dapat melihatnya dari berbagai segi. Pemahaman merupakan jenjang kemampuan berpikir yang setingkat lebih tinggi dari ingatan dan hafalan. Berdasarkan dari pengertian di atas, dapat disimpulkan bahwa pemahaman adalah mengetahui akan makna yang tersirat dari suatu hal. Jadi, memahami bukan sebatas mengetahui, tetapi mengetahui dan mengerti atas suatu hal.

\section{Agama Islam}

Agama berarti kepercayaan kepada tuhan dengan ajaran kebaktian dan kewajiban-kewajiban. Agama melibatkan seluruh fungsi jiwa dan raga manusia. Islam 
tidak hanya diperoleh melalui pengajaran, tetapi juga melalui proses pendidikan sebagaimana yang dicontohkan Nabi menggunakan aneka metode dan pendekatan sehingga dapat menyentuh hati penerima informasi.

Pendidikan Islam mengkolaborasikan antara ilmu dan amal. Jadi, pendidikan Islam bersifat teoritis dan praktis. Hal ini difungsikan guna mencapai kesejahteraan hidup individu maupun kelompok, maka pendidikan Islam adalah pendidikan individu dan pendidikan masyarakat (Mohtar, 2017). Semula yang bertugas mendidik adalah para Nabi dan Rasul selanjutnya diteruskan oleh para ulama.

Dalam Agama Islam, pendidikan itu merupakan perintah Allah dan merupakan suatu bentuk ibadah. Adapun ayat yang menjelaskan tentang pendidikan.

Allah SWT berfirman:

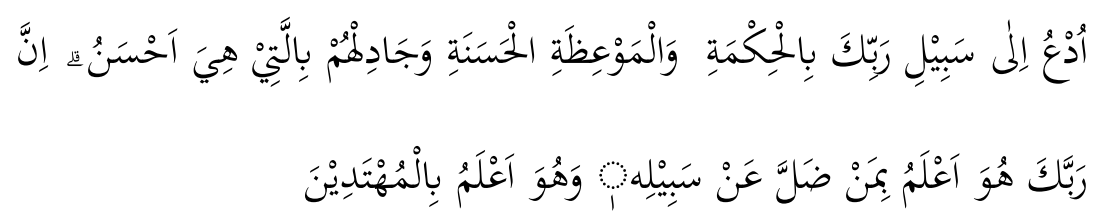

"Serulah (manusia) kepada jalan Tuhanmu dengan hikmah dan pengajaran yang baik, dan berdebatlah dengan mereka dengan cara yang baik. Sesungguhnya Tuhanmu, Dialah yang lebih mengetahui siapa yang sesat dari jalan-Nya dan Dialah yang lebih mengetahui siapa yang mendapat petunjuk."(QS. An-Nahl 16: Ayat 125)

Pendidikan Agama Islam, mencakup materi akhlak. Akhlak meliputi etika, budi pekerti, atau moral sebagai perwujudan dari pendidikan agama. Tujuan pendidikan agama Islam selaras dengan tujuan penciptaan manusia yaitu untuk beribadah kepada Allah. Oleh sebab itu, tujuan pendidikan Islam yaitu menjadikan peserta didik menjadi manusia yang beriman dan bertakwa kepada Tuhan Yang Maha Esa serta berakhlak mulia. Hal ini selaras dengan tujuan pendidikan Nasional dalam UU Sisdiknas Nomor 20 Tahun 2003. Dengan demikian, kuatnya iman seseorang akan terwujud dalam bentuk perbuatan.

\section{Ruang lingkup Agama Islam}

Ruang lingkup ajaran Islam meliputi tiga bidang yaitu aqidah, syari'ah dan akhlak. Aqidah menurut istilah ialah keyakinan hidup atau lebih khas lagi iman. Sesuai dengan maknanya aqidah ialah bidang keimanan dalam Islam dengan meliputi semua hal yang harus diyakini oleh seorang muslim/mukmin. Terutama sekali yang termasuk bidang aqidah ialah rukun iman yang enam, yaitu iman kepada Allah, kepada malaikat- 
malaikat-Nya, kepada kitab-kitab-Nya, kepada Rasul-rasul-Nya, kepada hari Akhir dan kepada qada'dan qadar.

Syari'ah ialah peraturan Allah yang mengatur hubungan manusia dengan tiga pihak yaitu: Tuhan, sesama manusia dan alam seluruhnya, peraturan Allah yang mengatur hubungan manusia dengan tuhan disebut ibadah, dan yang mengatur hubungan manusia dengan sesama manusia dan alam seluruhnya disebut Muamalah.

Muamalah meliputi munakahat (perkawinan), termasuk di dalamnya soal harta waris (faraidh) dan wasiat, Tijarah (hukum niaga) termasuk di dalamnya soal sewamenyewa, utang-piutang, wakaf, Hudud dan jinayat keduanya merupakan hukum pidana Islam.

Hudud ialah hukum bagi tindak kejahatan zina, tuduhan zina, merampok, mencuri dan minum-minuman keras. Sedangkan jinayat adalah hukum bagi tindakan kejahatan pembunuhan, melukai orang, memotong anggota, dan menghilangkan manfaat badan, dalam tinayat berlaku qishas yaitu "hukum balas".

Akhlak adalah bagian ajaran Islam yang mengatur tingkah laku perangai manusia. Ibnu Maskawaih mendefenisikan akhlak dengan "keadaan jiwa seseorang yang mendorongnya melakukan perbuatan-perbuatan tanpa melalui pertimbangan fikiran" (Amin, 2014).

Hasbi (2019) menjelaskan dalam hasil penelitiannya bahwa istilah lain dari akhlak adalah etika. Etika adalah suatu ilmu yang membahas masalah baik dan buruk, menerangkan apa yang seharusnya dilakukan oleh manusia kepada lainnya, menyatakan tujuan dari setiap perbuatan dan menunjukkan jalan untuk melakukan apa yang harus dilakukan. Jadi, etika adalah perbuatan baik yang timbul dari kesadaran diri dan atas unsur kesengajaan sehingga orang tersebut mengetahui benar apa yang diperbuat termasuk perbuatan baik atau buruk.

\section{Lembaga pemasyarakatan (Lapas)}

Lembaga pemasyarakatan atau biasa disebut lapas merupakan sebuah lembaga yang memuat sistem kemasyarakatan serta memberikan bimbingan-bimbingan yang bertujuan untuk meningkatkan kesadaran Narapidana atau eksistensinya sebagai manusia. Lembaga Pemasyarakatan sebagai instansi terakhir di dalam system peradilan pidana dan pelaksanaan putusan pengadilan (hukum) di dalam kenyataannya tidak 
mempersoalkan, apakah seseorang terbukti bersalah atau tidak (Irwan $\mathrm{P}$ dan Simonangkis, 1995).

Pancasila menjadi dasar pelaksanaan pembinaan di Lembaga Pemasyarakatan untuk meningkatkan kualitas warga binaan pemasyarakatan agar menyadari kesalahan. Lembaga pemasyarakatan berusaha untuk membina narapidana, mengenal diri sendiri menjadi lebih baik, menjadi positif, mengembangkan diri sendiri menjadi manusia yang lebih berguna bagi masyarakat, agama, nusa dan bangsa.

\section{Anak}

UU No. 23 Tahun 2002 tentang perlindungan anak memberikan definisi anak adalah seseorang yang belum berusia 18 tahun, termasuk anak yang masih dalam kandungan (Djamil, 2013). Anak menurut pasal 1 ayat (1) Undang-undang nomor 3 tahun 1997 adalah orang yang dalam perkara anak nakal telah mecapai 8 (delapan) Tahun tetapi belum mencapai 18(delapan belas) tahun dan belum pernah kawin. Sedangkan pengertian Narapidana menurut Undang undang Nomor 12 tahun 1995 tentang pemasyarakatn dalam pasal 1 ayat (7) yaitu "Terpidana yang menjalani pidana hilang kemerdekaan di Lapas". Dalam hal ini narapidana termasuk didalamnya anak pemasyarakatan,dan didalam undang-undang Nomor 12 tahun 1995 pasal 1 ayat (8) dijelaskan mengenai anak didik pemasyarakatan adalah:

1. Anak pidana yaitu : anak yang berdasarkan putusan pengadilan menjalani pidana di Lapas Anak paling lama sampai umur 18 Tahun.

2. Anak negara yaitu : anak yang berdasarkan putusan pengadilan diserahkan kepada negara untuk dididik dan di tempatkan di Lapas anak paling lama sampai umur 18 tahun.

3. Anak sipil yaitu: anak yang atas permintaan orang tua atau walinya memperoleh penetapan pengadilan untuk dididik di Lapas Anak paling lama sampai berusia 18 Tahun.

\section{Pidana Menurut Agama Islam}

Pengertian pidana menurut agama Islam yaitu larangan-larangan agama yang dilarang atau meninggalkan perbuatan yang diperintahkan agama. Balasan bagi orang yang melakukan tindak pidana adalah hukuman untuk memberikan efek jera. Hukuman itu sendiri bukanlah merupakan suatu kebaikan, bahkan suatu pengrusakan bagi si pembuat pidana itu sendiri. 
Pasal- pasal tentang pembinaan dan pendidikan keagamaan bagi anak didik di Lapas :

1. BAB III, pasal 9 UU no 23 tahun 2003 menyebutkan bahwa setiap anak berhak memperoleh pendidikan dan pengajaran dalam rangka pengembangan pribadinya dan tingkat kecerdasannya sesuai dengan minat dan bakatnya.

2. BAB II, pasal 21 ayat $1 \mathrm{~b}$, bahwa dalam hak anak yang melakukan tindakan pidana berumur 12 tahun wajib diikutsertakan pada program pendidikan, pembinaan dan pembimbingan.

3. Pasal 84 ayat 2 menyebutkan bahwa anak yang ditempatkan di Lapas berhak memperoleh pelayanan, perawatan, pendidikan, pelatihan, pembimbingan dan pendampingan, serta hak lain sesuai dengan ketentuan peraturan perundangundangan.

4. BAB VIII pasal 92 ayat 1 sampai ayat 4 membahas tentang pendidikan dan pelatihan yang harus diselenggarakan pemerintah yang dikoordinasikan dengan kementrian hukum.

5. UU Nomor 12 Tahun 1995 disebutkan bahwa pembinaan warga binaan pemasyarakatan dilakukan di Lapas dan Pembimbingan warga pemasyarakatan dilaksanakan oleh Bapas.

\section{METODE}

Metode penelitian ini menggunakan pendekatan kualitatif yaitu penelitian yang menghasiltakn data deskriptif berupa kata-kata tertulis dengan informasi dari orangorang dan perilaku yang dapat diamati. Data kualitatif ini diperoleh dengan melakukan observasi langsung, dengan tujuan untuk memperoleh gambaran mengenai pelaksanaan kegiatan keagamaan di lapas. Selain observasi, peneliti juga melakukan wawancara, yaitu suatu pedoman yang digunakan untuk melakukan tanya jawab agar pertanyaan tersebut terarah dengan baik. Pertanyaan tersebut diajukan kepada pihak-pihak yang terkait untuk memperoleh dan mengumpulkan data informasi mengenai masalah yang diteliti, dalam hal ini yaitu pasien dan staf pelaksanaan program di Lapas Anak Wanita Tangerang. Peneliti juga melakukan studi dokumentasi berupa dokumen resmi, suratsurat dan lainnya yang dapat dipakai untuk memperkuat data hasil wawancara.

\section{HASIL DAN PEMBAHASAN}


Lembaga permasyarakatan Kelas II B Anak Wanita Tangerang memiliki visi Memulihkan kesatuan hubungan hidup, kehidupan dan penghidupan WBP (warga binaan pemasyarakatan) sebagai individu, anggota masyarakat dan makhluk Tuhan YME. Misinya adalah melaksanakan perawatan tahanan pembinaan dan pembimbingan WBP dalam kerangka penagakan hukum pencegahan dan penanggulangan kejahatan serta pemajuan dan perlindungan Hak Asasi Manusia. Motto Lembaga permasyarakatan Kelas II B Anak Wanita Tangerang Bekerjalah secara Ikhlas dan cerdas karena itu adalah "IBADAH". Pembentukan WBP ditujukan agar menjadi manusia sebenarbenarnya, menyadari akan kesalahan yang dilakukan, berusaha untuk menjadi pribadi yang lebih baik dan tidak mengulangi tindak pidana yang sama sehingga dapat diterima kembali oleh lingkungan masyarakat, dapat aktif berperan dalam pembangunan dan dapat hidup secara wajar sebagai warga yang baik dan bertanggung jawab.

Sasaran pembinaan dan pembimbingan WBP, yaitu

a. Kualitas keimanan dan ketaqwaan kepada Tuhan YME

b. Kualitas pengetahuan

c. Kualitas sikap dan perilaku

d. Kualitas keterampilan

e. Kualitas kesehatan baik jasmani dan rohani

Tugas Pokok dan Fungsi Lapas Kelas IIB Anak Wanita Tangerang lebih condong pada bidang pendidikan, pelatihan, kursus untuk mengasah keterampilan sebagai bekal untuk memulai lembaran baru dalam kehidupan, bukan berorientasi pada masalah ekonomi. Pembinaan atau pendidikan yang dilaksanakan tetap mengedepankan pemenuhan hak-hak dan perlindungan anak serta keberpihakan pada anak.

Jumlah Warga Binaan Pemasyarakatan terdiri dari balita 13 orang, anak pidana 3 orang, napi kriminal 92 orang, napi narkoba 310 orang, napi kriminal WNA 2 orang, napi narkoba WNA 5 orang, tahanan kriminal 30 orang, tahanan narkoba 39 orang, tahanan kriminal wna 2 orang dan tahanan narkoba wna 11 orang.

Tabel 1. Kegiatan Harian di Lapas

\begin{tabular}{c|lc}
\hline Jam & \multicolumn{1}{c}{ Kegiatan Harian } \\
\hline \multirow{2}{*}{06.00} & Bangun pagi & \\
s/d & Apel pagi & \\
09.00 & Mandi cuci kaktus (MCK) & \\
\cline { 2 - 3 } & Makan pagi &
\end{tabular}




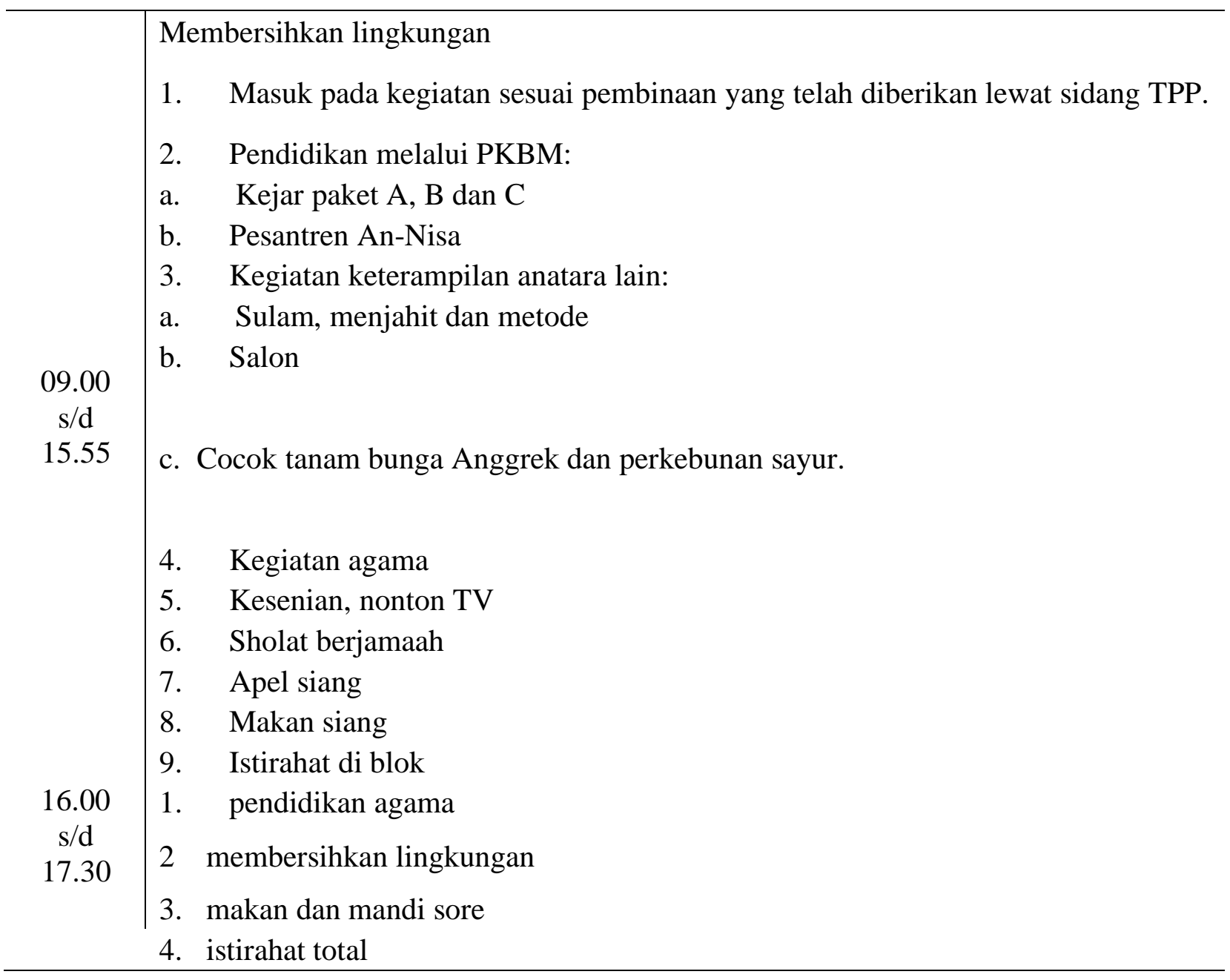

\section{Upaya Peningkatan Agama Islam di Lapas kelas IIB Anak Wanita Tangerang}

\section{Pembinaan kesadaran beragama}

Latar belakang pendidikan agama warga binaan tergolong kurang baik yang diperoleh dari pendidikan formal, informal maupun nonformal. Hal ini menjadi salah satu pemicu pelanggaran-pelangaran hukum yang dilakukan. Pembinaan keagamaan menjadi solusi yang tepat dalam menghadapi keanekaragaman sikap dan perbuatan yang jauh dari kata baik. Adanya pembinaan keagamaan diharapkan membawa manfaat bagi pribadi warga binaan sebagai umat beragama maupun sebagai bagian dari masyarakat. (Direktorat Jenderal Pemsyarakatan Kementrian Kehakiman dan Hak Asasi Manusia RI, 2001).

Sesuai dengan ketentuan, program mengenai wajib belajar baik rohani maupun jasmani yang diberikan adalah :

a. Belajar aqidah untuk menambah keimanan 
b. Belajar membaca Al-Qur'an

c. Belajar akhlak

d. Memberikan perlindungan antar anggota pavaliyun

\section{Kegiatan Keagamaan Islam}

Kegiatan keagamaan di Lapas kelas IIB Anak Wanita Tangerang dilakukan tiga kali dalam seminggu. Para pengajar disana secara sukarela memberikan ilmu dan pengetahuan agama. Terdapat 3 lembaga social kemasyrakatan yang secara sukarela dilakukan bergiliran sesuai jadwal mengajar yang telah disepakati. Berikut jadwal keagamaan Islam di Lapas Klas IIB Anak Wanita Tangerang:

a. Senin, oleh lembaga Dompet Dhuafa dengan pengajar yaitu: Ustadz. Dendi dan Umi $\mathrm{Hj}$. Siti Munawati M.Pd.I terdapat buku panduan dengan judul Fiqih Mualamah Wanita Modern yang disusun oleh Umi Hj. Siti Munawati M.Pd.I

b. Selasa, oleh lembaga ESQ dengan pengajar yaitu: Pak irvan dan Bunda Ratu dengan panduan Al-Qur'an.

c. Rabu, oleh UI dengan pengajar yaitu: Ustadz Imron dan Ustadz Mulyadi.

\section{Metode pembinaan yang dilakukan}

1. Metode Ceramah

Pembinaan yang dilakukan dengan memberikan uraian secara lisan dengan bahasa sehari-hari sehingga mudah diterima oleh para narapidana. Ceramah yang diselingi sedikit candaan agar tidak ngantuk dan membuat kesan yang kaku. Penggunaan metode ceramah bisa diintegrasikan dengan nasihat. Penjelasan yang disampaikan dengan metode ceramah memberikan pengetahuan dan mengingatkan kembali perbuatan yang sesuai dengan norma-norma agama.

Adapun materi yang disampaikan berupa fiqih, aqidah akhlak, Al-quran, Hadist, dan sejarah kebudayaan Islam. Untuk menghilangkan sikap pasif, Pembina juga menggunakan metode Tanya jawab. Metode ini dapat memancing antusias narapidana dalam memahami perihal yang disampaikan oleh penyuluh agama.

2. Metode pembelajaran Al-Quran

Tujuan utamanya memberantas buta huruf Al-Quran. Bagi yang belum bias membaca diberikan bimbingan dengan mengenalkan huruf-huruf hijaiyah yang menggunakan panduan iqro. Jika sudah bisa membaca al-quran, masing-masing diberikan kesempatan membaca sedangkan yang lainnya menyimak bacaan Al- 
Quran. Selain membaca mereka juga dibimbing ilmu tajwid kemudian dilanjutkan dengan membahas kandungan ayat.

3. Metode Muhasabah dan Dzikir

Intropeksi diri narapidana bisa diperoleh melalui metode muhasabah. Aspek yang dituju dari metode muhasabah adalah hati. Review perjuangan orang-orang terdekat menjadi kunci utama dalam menyentuh perasaan yang dipadukan dengan dzikir bersama.

Pembinaan disesuaikan dengan kondisi, metode nasehat, metode pembinaan individu, metode pembinaan kelompok, metode auto sugesti, metode ceramah, metode tanya jawab dan metode diskusi merupakan metode yang digunakan dalam pembelajaran Pendidikan Agama Islam di Lapas Kalas IIA Curup (Taklimuddin dan Saputra, 2017).

\section{Pengaruh Pendidikan Agama Islam Terhadap Mental Warga Binaan Lapas}

Pendidikan Agama Islam di Lapas anak membawa dampak positif berupa tumbuhnya iman dan takwa kepada Allah SWT, memberikan arahan agar warga binaan mempunyai pengetahuan keagamaan, melalui pembinaan keagamaan diharapkan Narapidana mendapatkan arahan pengetahuan aqidah, syariah dan akhlak serta dapat merealisasikannya dalam kehidupan sehari-hari.

Hasil penelitian yang dilakukan oleh Emqi (2014) menyatakan bahwa kegiatan keagamaan dengan menggunakan model pembelajaran PAI yang disesuaikan dengan kondisi di LP Kelas I Malang dan LP Wanita Kelas II-A Malang membawa perubahan pada akhlak, disiplin, dan tanggungjawab, solidaritas antar sesama narapidana dan toleransi. Hal tersebuat sesuai dengan visi misi dari kedua LP tersebut, diantaranya.

Pendidikan agama non formal dapat memberikan pengaruh tertentu dalam perkembangan mental penghuni lapas anak, antara lain:

a. Memberikan bimbingan dalam hidup

Pendidikan agama yang ditanamkan pada anak-anak akan menjadi unsurunsur kepribadiannya, karena keyakinan pada agama akan menjadi kepribadiannya dalam bersikap dan tingkah laku seseorang secara otomatis. Hal ini di jelaskan dalam firman ALLAH.

Allah SWT berfirman:

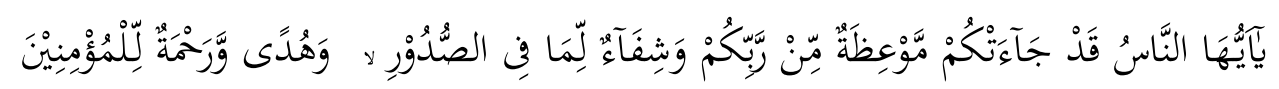


"Wahai manusia! Sungguh, telah datang kepadamu pelajaran (Al-Qur'an) dari Tuhanmu, penyembuh bagi penyakit yang ada dalam dada, dan petunjuk serta rahmat bagi orang yang beriman."(QS. Yunus 10: Ayat 57)

b. Menentramkan batin

Agama Islam merupakan landasan penting dalam membangun dan membina mental warga binaan karena agama akan memberikan jalan dan ketenangan pada jiwa yang gelisah. Sebagaimana firman Allah SWT dalam Qur'an surah

\section{Faktor Pendukung dan Penghambat Upaya Peningkatan Pemahaman Agama Islam di Lapas Kelas IIB Anak Wanita Tangerang}

Pelaksanaan Pendidikan Agama Islam di lapas kelas IIB anak wanita Tangerang terealisasi dengan baik, namun disisi lain upaya Pendidikan Agama dipengaruhi beberapa faktor, antara lain:

1. Faktor Penghambat

Kegiatan Pendidikan Agama Islam tentunya tidak terlepas dari berbagai macam kendala, diantaranya ialah:

a. Kegiatan keagamaan belum menyentuh jiwa warga binaan sehingga warga binaan belum merasakan dampak positif dari kegiatan keagamaan.

b. Fasilitas kegiatan keagamaan yang kurang terpenuhi seperti alat tulis, buku serta media pembelajaran.

c. Metode yang digunakan terkadang kurang efektif.

d. Kurangnya partisipasi narapidana dalam merespon apa yang disampaikan oleh penyuluh agama.

Arsyad (2017) juga menyatakan bahwa pihak pengelola (pembina) lapas dan rutan memiliki keterbatasan dalam mengimplementasikan pembinaan keagamaan, diantaranya: a) Rasio antara pembina dan WBP tidak seimbang; b) Pembinaan diaplikasikan secara alami; c) Pengetahuan pengelola (pembina) lapas/rutan tentang pengetahuan agama dan keagamaan diaktualisasikan berdasarkan pengalaman; d) Minimnya dukungan media dan fasilitas (buku-buku agama dan ruang) pembinaan; dan e) Jadwal kegiatan pembinaan belum konsisten.

2. Faktor Pendukung 
Kegiatan Pendidikan Agama Islam juga punya faktor yang mendukung kegiatan disana. Sebagai berikut

a. Adanya aturan hukum yang berkaitan dengan pelaksanaan kegiatan keagamaan di Lapas IIB Tangerang. Pelaksanaan kegiatan keagamaan sebagai bentuk implementasi dari pelaksanaan pembinaan kepribadian mempunyai dasar hukum yang jelas, diantaranya Undang- undang Dasar Negara Republik Indonesia Tahun 1945 pasal 29 tentang kemerdekaan untuk memeluk agama dan untuk beribadat menurut agama dan kepercayaannya. Undang- undang Republik Indonesia No. 12 Tahun 1995 Tentang Pemasyarakatan. Peraturan Pemerintah Republik Indonesia Nomor 31 Tahun 1995 tentang Materi yang disampaikan dalam pelaksanaan kegiatan keagamaan beragam.

b. Adanya jalinan kerjasama dengan pihak lain. Kegiatan PAI di Lapas klas IIB anak wanita Tangerang para pengajarnya dari lembaga sosial datang secara suka rela memberikan ilmu keagaman untuk para WBP.

\section{KESIMPULAN}

Kegiatan pendidikan agama Islam di Lapas klas IIB anak wanita Tangerang berjalan dengan baik dan postif. Disimpulkan bahwa upaya peningkatan pemahaman agama Islam dilakukan dengan menggunakan beberapa metode yang tidak berbeda dari metode bimbingan pada umumnya. Diantaranya seperti metode ceramah, metode pembelajaran al-quran, serta metode muhasabah dan dzikir. Hambatan yang terjadi dalam kegiatan pendidikan agam Islam ini yakni kurangnya kesadaran dari narapidana dalam melaksanakan proses kegiatan keagamaan dan kurangnya perhatian dari Pemerintah dalam pengadaan tenaga pendidik dan sarana prasana dalam pelaksanaan kegiatan keagamaan.

\section{DAFTAR PUSTAKA}

Amin, A. Rifqi. 2014. Sistem Pembelajaran Pendidikan Agama Islam pada Perguruan Tinggi Umum. Yogyakarta: Deepublish.

Arsyad, Abdul Rahman. 2017. Pembinaan Keagamaan Anak di Lembaga Pemasyarakatan di Kabupaten Bulukumba dan Bantaeng. EDUKASI: Jurnal 
Penelitian Pendidikan Agama dan Keagamaan, 15 (1), 109-125. Retrieved from http://jurnaledukasikemenag.org/index.php/edukasi/article/view/56/pdf

Departemen Pendidikan Nasional. 2005. Kamus Besar Bahasa Indonesia. Jakarta : Balai Pustaka

Direktorat Jenderal Pemasyarakatan Kementrian Kehakiman dan Hak Asasi Manusia RI. 2001. Petunjuk Pelaksanaan Program Pendidikan Agama Islam dengan Kurikulum Modul A Bagi Narapidana di Lembaga Pemasyarakatan dan Rumah Tahanan Negara. Jakarta, t.p.

Dirokterat Jendral permasyarakatan, Undang-undang No. 12 tahun 1995 Tentang permasyarakatan.

Djamil, M. Nasir. 2013. Anak Bukan Untuk dihukum. Jakarta: Sinar Grafika.

Emqi, Muhammad Fauzy. Model Pembelajaran Pendidikan Agama Islam dalam Pembinaan Mental Narapidana (Studi Multikasus di Lembaga Pemasyarakatan Kelas I Malang dan Lembaga Pemasyarakatan Wanita Kelas II-A Malang). J-PAI, $1 \quad$ (1), 49-65. Retrieved from http://103.17.76.13/index.php/jpai/article/view/3359/5170

Hasbi. 2019. Pendidikan Agama Islam Era Modern. Yogyakarta: Leutikaprio.

Irwan, P. Petrus dkk. 1995. Lembaga Pemasyarakatan Dalam Perspektif Sistem Peradilan Pidana. Jakarta: Sinar Harapan.

Kusnawan, Aep. 2011. Urgensi Penyuluhan Agama. Jurnal Ilmu Dakwah, 5 (17), 271 289. Retrieved from http://journal.uinsgd.ac.id/index.php/idajhs/article/view/367/378

Mohtar, Imam. 2017. Problematika Pembinaan Pendidikan Agama Islam Pada Masyarakat. Ponorogo: Uwais Inspirasi Indonesia.

Taklimudin dan Febri Saputra. 2017. Pendidikan Akhlak pada Napi Anak di Lapas Kelas IIa Curup. Belajea: Jurnal Pendidikan Islam, 2 (2), 157-179. Retrieved from http://journal.staincurup.ac.id/index.php/belajea/article/view/308/252 